\section{S0SIAfLL- Lä̈̈HETIETEELLINEW AIHAHAUSLEHTI}

Journal of Sogial Medicine

Päätoimittaja

Riikka Lämsä

riikka.lamsa@ helsinki.fi

Toimitussihteeri

Suvi Määttä

Puh. 0405937048

toimitussihteeri@socialmedicine.fi

Lehden internetsivut

http://journal.fi/sla

Julkaisija

Sosiaalilääketieteen yhdistys ry

Socialmedicinska föreningen of

Julkaisijan osoite

Sosiaalilääketieteen yhdistys

c/o Paula Jääskeläinen

PL 9 (Siltavuorenpenger IA)

00014 Helsingin yliopisto

Yhdistyksen puheenjohtaja

Hannamaria Kuusio

Terveyden ja hyvinvoinnin laitos

PL 30

0027 I Helsinki

Yhdistyksen sihteeri

Laura Pääkkö

sihteeri@socialmedicine.fi

Ilmestymisaikataulu

Neljä numeroa vuodessa (helmikuu, toukokuu, syyskuu ja joulukuu)

Kirjapaino ja taitto

Kirjapaino Hermes Oy

Tämä julkaisu on saanut TSV:n kautta tieteellisen julkaisutoiminnan avustusta, jota opetus- ja kulttuuriministeriö myöntää Veikkauksen tuotoista

ISSN 0355-5097

Kirjapaino Hermes Oy 2020

\title{
Luonnon ja yhteiskunnan kaksisuuntainen yhteys
}

Olemme kollektiivisesti eläneet elinaikamme ehkä omituisinta vuotta. Vuosi on päättymässä, mutta olosuhteet näyttävät valitettavasti jatkuvan ennallaan, jopa määräämättömän ajan.

Jotkut, hyvät asiat, ovat onneksi pysyneet: Sosiaalilääketieteellisiä aikakauslehtiä on tänäkin vuonna julkaistu neljä kappaletta ja lehti on löytänyt hyvin niin kirjoittajia kuin lukijoitakin. Yllätys oli, että syyskuussa 2020 julkaistusta Rokoteteemanumerosta tuli ajankohtaisempi kuin olimme ajatelleetkaan. Lehden uusimmassa podcastissakin keskustellaan rokotteista, muun muassa siitä, miltä rokotteiden pakollisuus näyttäytyy historiallisessa valossa. Podcastin löytää osoitteesta https://journal.fi/sla/slapodcast . Vuonna 2021 on vuorossa Kriisi-teemanumero, jossa pureudumme eri näkökulmista niin korona- kuin muihinkin kriiseihin.

Korona-aika on muuttanut lukemattomia asioita, joista konkreettisin lienee ihmisten välinen kanssakäyminen. Tämän lisäksi huomaan, että itse pandemia ja sen seurauksena meitä suojelemaan asetetut rajoitukset muuttavat suhdettamme tilaan, siis siihen fyysiseen ympäristöön, jossa elämme ja toimimme.

Ennen pandemiaa maailman voi sanoa olleen pieni: meillä länsimaisilla hyväosaisilla oli aina mahdollisuus lähteä. Meille oli mahdollistettu toisenlaisen maiseman, kulttuurin ja ihmisten saavuttaminen jo muutamassa tunnissa. Koronapandemia on palauttanut meidät aikaan, jolloin välimatkat ovat taas konkreettisia ja pitkiä. Matkustamisesta on tullut epäsuotavaa, ellei jopa kiellettyä, usein käytännössä mahdotonta tai ainakin hankalaa. Ristiriitaista on, että samalla maailma on pienempi kuin koskaan ja se on tullut kotiimme. Kokouksiin ja kansainvälisiin konfe- 
rensseihin, maailmanluokan konsertteihin ja näyttelyihin on ollut mahdollista osallistua ruokapöydästä, mökkilaiturilta ja välillä jopa suomalaisen rauhan tyyssijasta, saunan lauteilta.

Huomaan myös, että tilaan liittyvät käsitteet ovat saaneet uusia vivahteita. Vähän aikaa sitten "turvallinen tila" merkitsi paikkaa, jossa kaikenlainen häirintä oli kiellettyä ja jokainen sai olla omanlaisensa. Nykyään turvallisena tilana mainostetaan paikkoja, joissa pienenpienen viruksen leviäminen on estetty kaikin mahdollisin keinoin ja järjestelyin. Tai entä verbi "tehdä tilaa"? Aiemmin liitin siihen mielikuvan ihmisjoukosta ahtaassa tilassa, jossa ihmiset tiivistyvät vielä lähemmäs toisiaan, jotta mukaan mahtuisi. Nykyään sama ilmaus tuo mieleen kahden metrin turvavälit ja tarpeen siirtyä muista poispäin, ei muiden joukkoon.

Vuonna 2016 kuollut brittiläinen kulttuurimaantieteilijä Doreen Massey kuvasi tilan ja yhteiskunnan suhdetta sanomalla, että yhteiskuntaa tuotetaan tilallisesti ja yhteiskunnan tilallinen järjestäminen vaikuttaa siihen, miten yhteiskunta toimii. Koronapandemian aikana tämä tilan ja yhteiskunnan kaksisuuntainen yhteys on tullut konkreettisesti näkyväksi. Ja tekisi mieli lisätä kokonaisuuteen kolmaskin palanen: luonnontieteellinen ilmiö, maailmanlaajuinen pandemia, on tällä kertaa sysännyt liikkeelle muutosvoimat, jossa tilan ja yhteiskunnan olemisen tavat, mahdollisuudet ja tasapaino määrittyvät uudelleen. Tila toimii välittäjänä luonnon ja yhteiskunnan välissä. Tämä luonnon ja yhteiskunnan alati läsnä oleva ja kaikkinainen yhteys näkyy myös Sosiaalilääketieellisessä aikakauslehdessä. Tavoittelemme sisältöjä, jossa terveys ja sairaus, ruumis ja luonto konkretisoituvat sosiaalisessa ja yhteiskunnallisessa - ja toisinpäin. Tämä on ollut ja on jatkossakin lehtemme vahvuus.

RIIKKA LÄMSÄ, päätoimittaja

\title{
Sosiaaliläketieteellisen aikakauslehden kirjoituskutsu Kriisi -teemanumeroon
}

\begin{abstract}
Maailmanlaajuinen koronapandemia haastaa yhteiskuntamme terveydellisesti, sosiaalisesti, poliittisesti ja taloudellisesti. Käsillä olevalla kriisillä on kauaskantoisia seurauksia kaikilla näillä tasoilla. Paikallisia ja globaaleja kriisejä tulee eteemme jatkossakin. Sosiaalilääketieteellinen aikakauslehti haluaa olla jakamassa tutkittua tietoa aiheesta.
\end{abstract}

Kutsumme eri alojen tutkijoita kirjoittamaan vuonna 2021 julkaistavaan teemanumeroon vertaisarvioitavia, empiirisiä tai teoreettisia, tutkimusartikkeleita tai puheenvuoroja. Kirjoitukset voivat käsitellä korona- tai muita pandemioita tai laajasti erilaisia ympäristöterveydellisiä tai yhteiskunnallisia kriisejä esimerkiksi seuraavista näkökulmista:

- paikallisten ja globaalien krïsien historia, eteneminen, seuraukset

- pandemioihin varautuminen ja toiminta kriisitilanteessa

- kriisi esimerkiksi eriarvoisuuden, mielenterveyden, pakolaisuuden tai talouden näkökulmasta

- kriisin vaikutukset elintapoihin ja terveyskäyttäytymiseen (ruoka, päihteet, fyysinen aktiivisuus, uni)

- pandemian vaikutukset sosiaali- ja terveyspalvelujärjestelmään ja palveluihin

- kriisin mahdolliset opit ja positiiviset vaikutukset esimerkiksi ihmisten hyvinvointiin, palvelujen digitalisoitumiseen, ympäristökriisin ratkaisuun

- krïsistä käyty yhteiskunnallinen keskustelu

Lähetä enintään 250 sanan abstrakti kirjoituksesta osoitteeseen riikka.lamsa@ helsinki.fi viimeistään 15.I2.2020. Teemanumeroon liittyvät mahdolliset kysymykset voi osoittaa samaan osoitteeseen. 